\title{
Pie Substitusi Tepung Biskuit MP-ASI Kemenkes dan Isolat Protein Kedelai Sebagai Alternatif Pencegahan KEP Pada Anak Usia 12-24 Bulan
}

\section{Pie Substituted with Biscuit of MP-ASI Kemenkes and Soya Isolate Protein as an Alternate for Prevention of Protein Energy Malnutrition in Children Aged 12-24 Months}

\author{
Mufidah Ahmad*, Mahmud Aditya Rifqi
}

\begin{abstract}
ABSTRAK
Latar Belakang: Pemerintah berupaya melakukan pencegahan KEP pada anak usia 12-24 bulan melalui program pemberian Makanan Pendamping Air Susu Ibu (MP-ASI) yang berupa biskuit. Setelah dilakukan evaluasi, biskuit MP-ASI Kemenkes RI memiliki daya terima yang rendah, karena memiliki rasa pahit diakhir dan mengalami titik jenuh kebosanan. Oleh karena itu perlu adanya inovasi untuk meningkatkan daya terima MP-ASI dengan memodifikasi biskuit menjadi bentuk pie dengan fla yang memiliki rasa yang disukai dan lebih menarik bagi anak usia tersebut.

Tujuan: Mengetahui formula terbaik pie yang disubstitusi dengan biskuit MP-ASI dan isolat protein kedelai; menganalisis perbedaan daya terima pada formula kontrol, formula terbaik dan biskuit Mp-ASI; Membandingkan kandungan zat gizi makro dan anjuran porsi konsumsi pie formula terbaik dengan biskuit MP-ASI.

Metode: Desain penelitan ini adalah Eksperimental dengan Rancangan Acak Lengkap (RAL). Terdapat 1 formula kontrol (F0) dan 3 formula modifikasi (F1,F2,F3). Masing-masing formula tersusun dari komposisi tepung terigu, tepung biskuit MP-ASI Kemenkes dan isolat protein kedelai : F0 (100\%, 0\%, 0\%); F1 (85\%, 10\%, 15\%); F2 (60\%, 20\%, 20\%); F3 (45\%, 30\%, 25\%). Pemilihan formula terbaik melalui pembobotan dari hasil perhitungan kandungan gizi berdasarkan DKBM dan hasil uji hedonik oleh 3 panelis ahli. Formula kontrol, Formula terbaik dan biskuit MP-ASI dilakukan uji hedonik kepada 25 panelis anak usia 12-24 bulan beserta ibunya. Perbedaan daya terima diketahui melalui uji Friedman dan Wilcoxon Sign Rank.

Hasil: Formula pie modifikasi terbaik adalah F2. Hasil uji daya terima F0, F2 dan biskuit MP-ASI mendapatkan nilai rata-rata tingkat kesukaan $(2,1),(2,5)$ dan $(1,6)$. Kandungan zat gizi energi, protein, karbohidrat dan lemak tiap $100 \mathrm{~g}$ F2 lebih rendah dibandingan biskuit MP-ASI. Anjuran porsi konsumsi F2 dan biskuit MP-ASI per hari adalah 4 keping dan 12 keping.

Kesimpulan: Formula Pie terbaik adalah F2. Daya terima F2 lebih tinggi daripada biskuit MP-ASI. Meskipun kandungan zat gizi makro pada pie F2 tiap $100 \mathrm{~g}$ masih lebih rendah dibandingkan biskuit MP-ASI, tetapi jumlah anjuran konsumsi sajian F2 lebih sedikit dibandingkan biskuit MP-ASI.
\end{abstract}

Kata Kunci: Kurang Energi Protein, MP-ASI, Pie

\section{ABSTRACT}

Background: The government prevent Protein Energy Malnutrition (PEM) by implemented a feeding program of companion breast milk (MP-ASI) in the form of biscuits. After the evaluation, MP-ASI biscuit from Department of Health has a low acceptability, because it has a bitter taste and experience the saturation point of boredom. Therefore, researchers innovate to improve acceptance by modifying biscuits into pie shapes fla that have a preferred flavor and more appealing to children.

Objective: to assess the best pie formula substituted with MP-ASI biscuit and soya isolate protein; to analyze the differences acceptability in control formula (FO), the best formula (F2), and MP-ASI biscuit; comparing the macro nutrient contained and the recommended portion of the best pie formula and MP-ASI biscuit.

Method: This research design was Experimental with Completely Randomized Design (CRD). There were 1 control formula and 3 modification formula (F1, F2, F3). Each formula contained wheat flour, MP-ASI biscuit and soy protein isolate: FO (100\%, 0\%, 0\%); F1 (85\%, 10\%, 15\%); F2 (60\%, 20\%, 20\%); F3 (45\%, 30\%, 25\%). Selection of the best formula through weighing score from the calculation nutrition contained based on DKBM and hedonic test result by 3 expert panelists. The control formula, the best 
formula and MP-ASI biscuit were hedonic tested on 25 panelists of children aged 12-24 month and their mothers. The difference in acceptability was known through the Friedman test and Wilcoxon Sign Rank.

Results: The best pie formula modification was F2. The results of the acceptability test of FO, F2 and MP-ASI biscuits get the mean rank value of preference levels (2.1), (2.5) and (1.6). The nutrient contained of energy, protein, carbohydrates and fat per $100 \mathrm{~g}$ F2 was lower than the MP-ASI biscuit. The recommended portion of F2 consumption and MP-ASI biscuits per day was 4 pieces and 12 pieces.

Conclusion: The best pie formula was F2. The acceptability of F2 was higher than MP-ASI biscuit. Although the macro nutrient contained in F2 pie per $100 \mathrm{~g}$ was still lower than MP-ASI biscuit, the recommended amount of F2 serving was less than MP-ASI biscuit

Keywords: Protein Energy Deficiency, MP-ASI, Pie.

\author{
*Koresponden: \\ Mufidah Ahmad \\ mufidah.ahmad-2015@fkm.unair.ac.id \\ Departemen Gizi Kesehatan, Fakultas Kesehatan Masyarakat-Universitas Airlangga
}

\section{PENDAHULUAN}

Berdasarkan hasil Pemantauan Status Gizi Tahun 2016 Baduta (Anak dibawah Dua Tahun) sebanyak 3,1 memiliki status gizi buruk dan $11,8 \%$ memiliki status gizi kurang ${ }^{1}$. Status gizi buruk dan kurang ini disebabkan Kekurangan Energi dan Protein (KEP) yang terjadi secara terus menerus dalam waktu yang lama². Usia Baduta merupakan masa kritis dalam proses tumbuh kembang anak baik fisik maupun kecerdasannya ${ }^{3}$.

Kemenkes RI telah melakukan pengadaan MP-ASI untuk anak usia 12-24 bulan berupa biskuit yang mengandung zat gizi makro, sepuluh jenis vitamin dan tujuh jenis mineral yang diperlukan oleh kelompok usia sasaran, khususnya yang memiliki status berat badan Bawah Garis Merah (BGM) ${ }^{4}$. BGM merupakan gambaran status gizi balita yang mengalami Kurang Energi Protein (KEP) sedang atau berat ${ }^{5}$. Setelah diproduksi secara massal dan didistribusikan, ternyata biskuit tersebut memiliki daya terima yang rendah. Hal ini dikarenakan anak tidak menyukai rasa akhir biskuit ${ }^{6}$. Selain itu, anak merasa bosan dan tidak mampu menghabiskan jumlah biskuit sesuai takaran porsi dan lama pemberian yang dianjurkan yaitu sebanyak 12 keping biskuit per hari atau setara dengan 120 g selama 90 hari ${ }^{3,7}$. Oleh karena itu diperlukan variasi MPASI dalam bentuk yang lain, dan upaya inovasi untuk meningkatkan daya terima dengan memodifikasi biskuit menjadi bentuk MP-ASI yang lebih menarik dan memiliki rasa yang disukai kelompok usia sasaran.

Pie merupakan salah satu bentuk makanan yang populer di dunia, dan mulai diterima oleh masyarakat lokal sebagai jajanan popular. Penerimaan pie di masyarakat menjadikan makanan ini tepat difungsikan sebagai inovasi bentuk MP-ASI yang baru untuk anak usia 12-24 bulan. Pie terdiri dari dua komponen yaitu crust dan isi. Pada bagian crust dilakukan substitusi bahan, yaotu tepung terigu disubstitusi dengan biskuit MP-ASI yang ditepungkan dan isolat protein. Tekstur padat pada crust pie ini cocok dikenalkan pada anak usia 12-24 bulan karena kemampuan mengunyah anak saat usia ini sudah mulai terlatih ${ }^{8}$. Pada bagian isi pie masyarakat Indonesia biasanya menggunakan krim fla, buah-buahan, dan agar-agar. Dalam hal ini, pie biskuit MP-ASI dengan dapat dihidangkan dengan krim fla yang terbuat dari bahan pangan yang berbasis kearifan lokal, yaitu ubi ungu. Ubi ungu memiliki mutu yang baik ditinjau dari kandungan gizinya, terutama karbohidrat, vitamin dan mineral. Kandungan vitamin $A$ pada ubijalar dalam bentuk provitamin A mencapai 9.000 SI/100 g, Vitamin B1, B6 ,dan niasin cukup memadai jumlahnya pada ubijalar. Kandung kalium, fosfor, kalsium, natrium, dan magnesium pada ubijalar juga tinggi ${ }^{9}$. Ketersediaan ubi yang melimpah serta berpotensi dijadikan tepung ubi ungu yang dapat diproduksi secara massal ${ }^{10}$.

Tujuan penelitian ini adalah untuk mengetahui formula pie terbaik dengan proporsi subtitusi yang berbeda, menganalisis kadar zat gizi makro (karbohidrat, protein dan lemak) dan mengetahui daya terima dari pie yang disubstitusi dengan biskuit MP-ASI Kemenkes RI dan isolat protein kedelai. Pie ini diharapkan dapat memberikan manfaat yaitu sebagai produk MP-ASI yang dapat digunakan sebagai alternatif pencegahan KEP pada anak usia 12-24 bulan.

\section{METODE}

Metode yang digunakan pada penelitian ini adalah eksperimental murni pada tahap pengembangan formula dengan memberikan perlakuan berupa proporsi bahan baku yang berbeda-beda pada tiap formula pie terutama pada bagian crust. Sedangkan pada tahap uji daya terima, penelitian ini menggunakan metode eksperimental semu yaitu untuk menguji adanya pengaruh perlakuan terhadap pie. Rancangan percobaan yang digunakan adalah Rancangan Acak Lengkap (RAL).

Penelitian ini terdiri dari 2 tahapan. Tahapan yang pertama yaitu penelitian pendahuluan untuk menentukan formula pie terbaik dengan mempertimbangkan kandungan gizi melalui perhitungan berdasarkan DKBM ${ }^{11}$ dan hasil uji organoleptik oleh panelis ahli yang terdiri dari tiga orang dosen program studi IImu Gizi Fakultas Kesehatan Masyarakat Universitas Airlangga. Tahapan yang kedua adalah penelitian lanjutan yang terdiri dari uji laboratorium kandungan zat gizi makro (karbohidrat, protein dan lemak) pada pie dengan formula

\title{
C2019. Ahmad dan Rifqi. Open access under CC BY - SA license.
}

Received: 11-07-2019, Accepted: 19-08-2019, Published online: 27-12-2019.

doi: 10.20473/amnt.v3.i4.2019 284-290, Joinly Published by IAGIKMI \& Universitas Airlangga 
terbaik dan uji daya terima pada panelis tidak terlatih. Panelis tidak terlatih adalah anak usia 12-24 bulan beserta ibunya berjumlah 25 orang yang dipilih secara acak di Posyandu wilayah kerja puskesmas Tenggilis Mejoyo. Pada uji daya terima ini, panelis diberikan sampel berupa produk pie formula kontrol (FO), Formula terbaik (F2) dan biskuit MP-ASI Kemenkes RI masing-masing sempel $5 \mathrm{~g}$.

Tabel 1. Formula dan Proporsi Bahan Pembuatan Pie

\begin{tabular}{llll}
\hline Formula & $\begin{array}{l}\text { Tepung } \\
\text { Terigu }\end{array}$ & $\begin{array}{l}\text { Tepung Biskuit } \\
\text { MP-ASI }\end{array}$ & $\begin{array}{l}\text { Isolat Protein } \\
\text { Kedelai }\end{array}$ \\
\hline F0 & $100 \%$ & $0 \%$ & $0 \%$ \\
F1 & $85 \%$ & $10 \%$ & $15 \%$ \\
F2 & $60 \%$ & $20 \%$ & $20 \%$ \\
F3 & $45 \%$ & $30 \%$ & $25 \%$ \\
\hline
\end{tabular}

Alat yang digunakan dalam pembuatan produk pie adalah timbangan digital, baskom plastik, sendok, rolling pin, cetakan pie, panci, dan oven. Bahan utama yang digunakan untuk membuat crust pie adalah Tepung terigu, mentega, gula bubuk, telur dan garam. Pada bagian crust ini dilakukan substitusi pada bahan tepung terigu dengan biskuit MP-ASI kemenkes yang ditepungkan dan isolat protein dari kedelai. Adapun bahan pembuatan fla terdiri dari Tepung sagu, gula pasir, susu bubuk dan tepung ubi ungu. Formula dan proporsi masing-masing bahan untuk formula kontrol (F0) dan formula perlakuan (F1, F2, dan F3) terdapat pada tabel 1. Adapun kerangka konsep pembuatan pie dijelaskan pada gambar

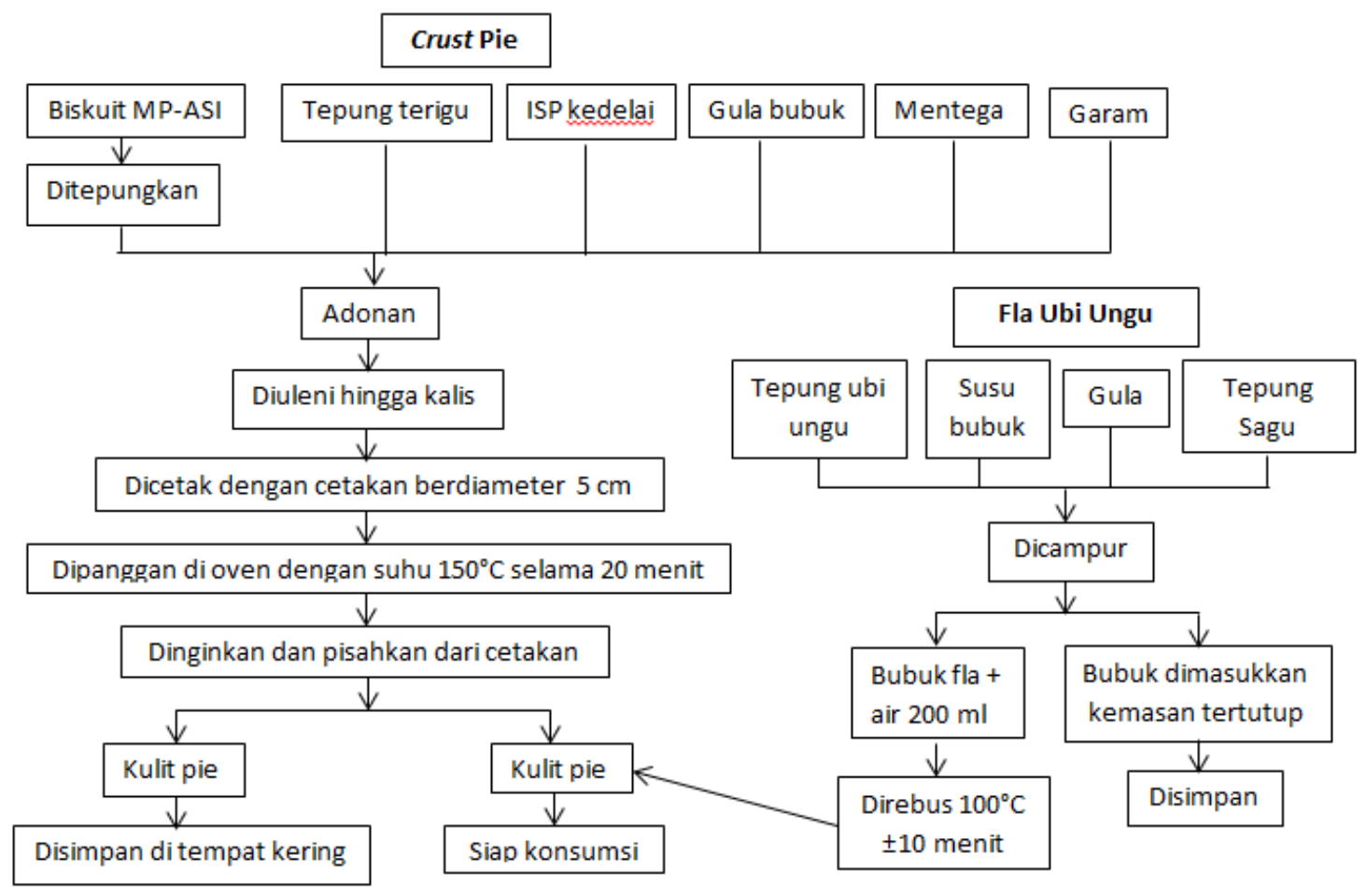

Gambar 1. Alur Proses Pembuatan Pie

Analisis kandungan gizi pie dilakukan berdasarkan informasi gizi dari kemasan yang tercantum pada bahan pembuatan pie dan DKBM serta menggunakan software Nutrisurvey 2007. Sedangkan analisis significancy pada daya terima dilakukan menggunakan software IBM SPSS. Untuk mengetahui adanya pengaruh substitusi tepung biskuit MP-ASI Kemenkes RI dan Isolat protein kedelai terhadap sifat organoleptik Pie dilakukan menggunakan uji statistik Anova Friedman Test $(\alpha=0,05)$. Sedangkan untuk mengetahui adanya pasangan yang berbeda, dilakukan uji Wilcoxon Signed rank $(\alpha=0,05)$.

\section{HASIL DAN PEMBAHASAN}

Penentuan Formula Terbaik

Penentuan Formula terbaik dilakukan dengan mempertimbangkan hasil perhitungan kandungan zat gizi makro tiap 100 gram bahan formula pie beradasarkan DKBM Indonesia dan hasil uji hedonik atau tingkat kesukaan oleh panelis ahli. Setelah itu dilakukan pembobotan sesuai dengan memberikan score 1 sampai 3 . Pemberian score ini didasarkan urutan penilaian formula

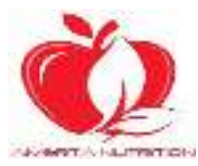

C2019. Ahmad dan Rifqi. Open access under CC BY - SA license.

Received: 11-07-2019, Accepted: 19-08-2019, Published online: 27-12-2019.

doi: 10.20473/amnt.v3.i4.2019 284-290, Joinly Published by IAGIKMI \& Universitas Airlangga 
terhadap masing-masing aspek kandungan gizi dan karakteristik uji hedonik. Semakin tiggi urutan penilaian formula kan mendapatkan bobot score semakin besar.

Hasil perhitungan kandungan zat gizi makro masing-masing formula pie dapat dilihat pada Tabel 2 . Formula pie modifikasi yang memiliki kandungan energi, protein dan lemak seacara berurutan dari tinggi ke rendah adalah F3, F2, dan F1. Sedangkan urutan kandungan karbohidrat dari tinggi ke rendah adalah F1, F2, dan F3. Pola ini menunjukkan adaya perubahan peningkatan kandungan energi, protein dan lemak tetapi berbanding terbalik pada kandungan karbohidrat mengalami penurunan akibat substitusi tepung terigu dengan tepung biskuit MP-ASI dan isolat protein. Tepung biskuit MP-ASI merupakan sumber lemak, sehingga apabila jumlah tepung biskuit MP-ASI yang disubstitusikan pada formula pie ditambah, maka kandungan lemak juga bertambah. Semakin bertambah kandungan lemak maka kandungan energi juga ikut meningkat, karena lemak menyumbangkan energi terbesar diantara zat gizi makro laninya yaitu 9 kalori tiap 1 gramnya. Isolat protein kedelai merupakan sumber protein, sehingga semakin banyak ditambahkan isolat protein kedelai pada formula pie maka kandungan protein juga semakin tinggi. Tepung terigu merupakan sumber karbohidrat, sehingga jika semakin dikurangi jumlah tepung terigu pada formula pie maka kandungkan karbohidratnya semakin rendah.

Tabel 2. Kandungan Zat gizi Makro tiap 100 gram Bahan formula Pie Berdasarkan DKBM Indonesia

\begin{tabular}{llcll}
\hline Formula & Energi (Kkal) & \multicolumn{2}{c}{ Kandungan Zat Gizi Makro Pie (zat gizi / 100 g bahan) } \\
& Protein (gram) & Lemak (gram) & Karbohidrat (gram) \\
\hline F0 & 6.3 & 15.5 & 59.5 \\
F1 & 9.1 & 16.5 & 56 \\
F2 & 9.4 & 16.6 & 54.7 \\
F3 & 416.7 & 10 & 17.5 & 54.1 \\
\hline
\end{tabular}

Penilaian uji hedonik dilakukan oleh panelis ahli terhadap karakteristik pie meliputi warna, aroma, rasa dan tekstur. Uji ini dilakukan dengan cara scoring 1 sampai 4 . Distribusi tingkat kesukaan panelis ahli terhadap formula control dan formula modifikasi ditunjukkan pada tabel 3 . Jika dinilai berdasarkan warna dan aroma, semua formula pie dengan substitusi memiliki aroma yang sama tetapi jika dibandingkan dengan formula control (FO) masih lebih baik F0. Panelis ahli menilai tekstur F2 sama baiknya dengan F0. Penilaian keseluruhan tingkat kesukaan pie oleh panelis ahli menunjukkan urutan kesukaan panelis adalah F0, F2, F3 dan F1. Dengan demikian, Formula pie modifikasi yang mendapatkan penilaian paling baik menurut panelis ahli adalah F2.
Pembobotan dilakukan berdasarkan parameter penilaian kandungan gizi pie hasil perhitungan berdasarkan DKBM yang terdiri dari energi, karbohidrat, protein, dan lemak, serta penilaian daya terima oleh panelis ahli yang meliputi warna, aroma, tekstur dan rasa. Berdasarkan hasil pembobotan didapatkan urutan formula dari total nilai tertinggi yaitu F2, F3 dan F1 dengan masing-masing nilai sebesar 19, 18 dan 12 . Pada F2 jika dilihat berdasarkan kandungan gizi energi, protein, lemak dan karbohidrat mendapatkan nilai tengah-tengah diantara F1 dan F3, artinya bukan yang tertinggi atau terendah. Tetapi, jika dilihat berdasarkan warna, tekstur dan rasa F2 ini mendapatkan nilai tertinggi diantara F1 dan F3. Maka dapat disimpulkan formula terbaik adalah F2 karena secara keseluruhan mendapatkan nilai bobot tertinggi.

Tabel 3. Distribusi Tingkat Kesukaan Panelis Ahli terhadap Warna, Aroma, Tekstur, serta Rasa Pie Kontrol dan Modifikasi

\begin{tabular}{|c|c|c|c|c|}
\hline \multirow[b]{2}{*}{ Karakteristik } & \multicolumn{3}{|c|}{ Formula } & \multirow[b]{2}{*}{ F3 } \\
\hline & F0 & F1 & F2 & \\
\hline Warna & 4 & 3 & 3 & 3 \\
\hline Aroma & 4 & 3 & 3 & 3 \\
\hline Tekstur & 4 & 2,3 & 4 & 3 \\
\hline Rasa & 4 & 2,3 & 3,4 & 2,3 \\
\hline Rata-rata & 4 & 2,65 & 3,35 & 2,82 \\
\hline
\end{tabular}

\section{Uji Daya Terima}

Perbedaan daya terima pada formula kontrol, formula terbaik dan biskuit Mp-ASI Kemenkes RI dapat diketahui melalui uji daya terima. Uji daya terima dilakukan menggunakan uji kesukaan panelis tidak terlatih (ibu Baduta) terhadap karakteristik warna, aroma, tekstur dan rasa. Hasil analisis Friedment Test penilaian tingkat kesukaan panelis ibu Baduta dapat dilihat pada tabel 4 . Selain itu juga dilakukan uji kesukaan pada anak 12-24 bulan dengan skala penilaian yang lebih sederhana yaitu meliputi suka dan tidak suka. Hasil analisis Friedment Test penilaian tingkat kesukaan panelis anak 12-24 bulan disajikan pada tabel 5. Apabila terdapat perbedaan daya terima yang signifikan, maka dilakukan uji lanjut menggunakan analisis Wilcoxon Signed Rank Test. Hasil analisis lanjutan ditunjukkan pada tabel 6 .

Penilaian daya terima oleh panelis tidak terlatih (ibu Baduta) terhadap tingkat kesukaan warna yang mendapat penilaian tertinggi adalah pie dengan formula kedua $(F 2)$ (mean rank $=2.32$ ), kemudian disusul dengan

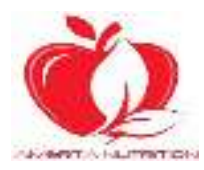

(C)2019. Ahmad dan Rifqi. Open access under CC BY - SA license.

Received: 11-07-2019, Accepted: 19-08-2019, Published online: 27-12-2019.

doi: 10.20473/amnt.v3.i4.2019 284-290, Joinly Published by IAGIKMI \& Universitas Airlangga 
pie formula kontrol (mean rank $=2.16$ ) dan yang mendapat penilaian terendah adalah biskuit kemenkes RI (mean rank= 1.52). Pada F2 penampakan warna crust pie lebih agak coklat dibandingkan FO cenderung pucat karena pengaruh penambahan isolat protein kedelai. Meskipun demikian tidak terdapat perbedaan yang bermakna antara F0 dan F2 $(p=0,083)$, artinya warna pada F0 dan F2 samasama disukai. Sedangakn jika dibandingkan antara pie FO dengan biskuit MP-ASI serta pie F2 dengan biskuit MP-ASI terdapat beda tingkat kesukaan yang signifikan $(p=0,02)$ dan $(P=0,00)$. Warna Pie lebih disukai dibandingkan biskuit MP-ASI karena pada pie terdapat isian fla ubi ungu yang memberikan variasi warna ungu. Menurut panelis tidak terlatih (ibu Baduta) variasi warna ungu menjadikan anak tertarik dan ingin mencoba memakannya. Hal ini dikarenakan pada usia 12-24 bulan anak mengalami perkembangan kemampuan membedakan warna ${ }^{8}$. Adanya variasi warna pada makanan anak juga sesuai dengan anjuran Pembinaan Pendidikan Aak Usia Dini (PAUD). Anak usia 12-24 bulan menyukai bermain ketika makan. Anak perlu diberi kesempatan untuk makan sendiri, dan juga perlu diberikan variasi warna pada makanannya karena warna makanan dapat menarik anak untuk memerhatikan dan menggunakannya sebagai alat untuk belajar ${ }^{14}$.

Tabel 4. Rata-rata Tingkat Kesukaan Panelis Tidak Terlatih (Ibu Baduta) Terhadap Daya Terima Pie formula kontrol (F0), Pie Formula Terbaik (F2), dan Biskuit MP-ASI

\begin{tabular}{ccccc}
\hline & & Formula & & P-Value \\
\cline { 2 - 4 } Karakteristik & F0 & F2 & Biskuit MP-ASI & 0,000 \\
Warna & 2,16 & 2,32 & 1,52 & 0,002 \\
Aroma & 2,1 & 2,22 & 1,68 & 0,002 \\
Tekstur & 1,92 & 2,22 & 1,86 & 0,000 \\
Rasa & 2,4 & 2,26 & 1,34 & \\
\hline Rata-rata & 2,145 & 2,255 & 1,6 & \\
\hline
\end{tabular}

Tabel 5. Rata-rata Tingkat Kesukaan Panelis Tidak Terlatih (Anak 12-24) Terhadap Daya Terima Pie formula kontrol (F0), Pie Formula Terbaik (F2), dan Biskuit MP-ASI

\begin{tabular}{ccccc}
\hline & \multicolumn{4}{c}{ Formula } \\
\cline { 2 - 4 } Karakteristik & F0 & F2 & Biskuit MP-ASI & P-Value \\
\hline Tingkat kesukaan & 2,18 & 2,24 & 1,58 & 0,000 \\
\hline
\end{tabular}

Pada aspek aroma, hasil penilaian terbaik adalah pie dengan F2 (mean rank=2.22), selanjutnya pie formula kontrol (mean rank=2.1) dan yang mendapat penilaian terendah adalah biskuit MP-ASI. Jika dibandingkan antara F0 dengan pie F2, keduanya tidak ada beda yang signifikan $(p=0.157)$ mempunyai kesamaan aroma yang netral. Sedangkan aroma pie formula kedua (F2) dibandingkan biskuit MP-ASi berbeda secara signifikan signifikan $(p=0.07)$. Berdasarkan keterangan panelis ibu baduta yang dituliskan di kuesioner uji organoleptik, Biskuit MP-ASI kemenkes RI memiliki aroma susu yang kuat sehingga cenderung membosankan. Hal ini diperkuat dengan laporan hasil evaluasi pelaksanaan program pemberian biskuit MP-ASI untuk balita kurus pada tahun 2017 yang menunjukkan daya terima balita kurus terhadap biskuit sebesar $32,2 \%$. Daya terima yang rendah ini disebabkan karena balita merasa bosan ${ }^{12}$.

Tabel 6. Perbedaan Rata-rata Tingkat Kesukaan Panelis Ibu dan Anak Usia 12-24 Bulan Pada Formula yang Dipasangkan

\begin{tabular}{cccc}
\hline & \multicolumn{3}{c}{ Pasangan Formula } \\
\cline { 2 - 4 } Karakteristik & F0 dan F2 & F0 dan FBiskuit MP-ASI & F2 dan Biskuit MP-ASI \\
\hline Panelis Ibu Baduta & & & 0,00 \\
\hline Warna & 0,083 & 0,02 & 0,07 \\
Aroma & 0,157 & 0,02 & 0,03 \\
Tekstur & 0,083 & 0,02 & 0,00 \\
\hline Rasa & 0,180 & 0,00 & 0,001 \\
\hline Panelis Anak 12-24 Bulan & & & 0,002 \\
\hline Kesukakaan & 0,317 & & \\
\hline
\end{tabular}

Pada aspek tekstur yang mendapat penilaian tertinggi adalah pie dengan formula kedua (F2) (mean rank=2.22), kemudian pie dengan formula kontrol
(F0)(mean rank=1.92) dan yang mendapat penilaian terendah adalah bikuit MP-ASI Kemenkes RI (mean rank= 1.86). Pada pie FO dan F2 memiliki tekstur yang tidak

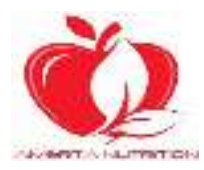

C2019. Ahmad dan Rifqi. Open access under CC BY - SA license.

Received: 11-07-2019, Accepted: 19-08-2019, Published online: 27-12-2019.

doi: 10.20473/amnt.v3.i4.2019 284-290, Joinly Published by IAGIKMI \& Universitas Airlangga 
berbeda signifikan $(p=0.083)$, sedangkan F2 dibandingkan dengan biskuit MP-ASI memiliki beda yang signifikan $(p=0.035)$. Hal ini dikarenakan tekstur biskuit lebih keras dibandingkan dengan tekstur pie menurut penilaian panelis ibu baduta. Berdasarkan petunjuk teknis Kementrian Kesehatan RI tahun 2017 tentang pemberian biskuit MP-ASI untuk baduta, tekstur biskuit MP-ASI memang dibuat renyah dan akan menjadi lembut jika dicampur dengan cairan ${ }^{3},{ }^{15}$. Biskuit ini dibuat satu jenis untuk anak usia 6 sampai 59 bulan, yang membedakan hanya porsi biskuit yang harus dihabiskan disesuaikan dengan kebutuhan gizi pada masing-masing usia. Jika biskuit dikonsumsi untuk anak usia 6-12 bulan dapat ditambahkan cairan sehingga teksturnya menjadi lembut. Sedangkan untuk anak usia 12-24 bulan, seiring dengan perkembangan usianya anak lebih menyukai makanan yang dapat dipegang sendiri ${ }^{8}$, sehingga tidak cocok apabila biskuit dibuat lumat dengan menambahkan cairan. Tetapi pada anak usia ini pertumbuhan gigi terjadi secara bertahap dan belum sempurna ${ }^{8}$, sehingga apabila biskuit dikonsumsi secara langsung tekstur biskuit terasa keras.

Pada aspek rasa yang mendapat penilaian tertinggi adalah Formula kontrol pie (FO) (mean rank= 2.4), selanjutnya pie dengan formula kedua (F2) (mean rank= 2.26) dan yang mendapat penilaian terendah adalah biskuit MP-ASI kemenkes RI (mean rank=1.34). Pada pie formula kontrol dan formula kedua tidak memiliki beda yang signifikan $(p=0.18)$ sedangkan formula pie (F2) memiliki beda yang signfikan jika dibandingkan dengan biskuit MP-ASI $(p=0.0)$. Berdasarkan tanggapan panelis ibu baduta pada kuesioner uji organoleptik rasa biskuit cenderung tidak disukai karena menimbulkan rasa pahit di akhir. Hal ini didukung dengan laporan hasil evaluasi program pemberian pemberian makanan tambahan pemulihan pada balita kurang gizi di Kabupaten Wonogiri yang menunjukkan bahwa balita tidak mau menghabiskan biskuit sesuai dengan porsi yang dianjurkan dikarenakan rasa biskuit di akhir yang tidak disukai ${ }^{6}$.

Penilaian tingkat kesukaan oleh panelis tidak terlatih (anak) menunjukan penilaian kesukaan tertinggi pada pie dengan formula modifikasi (F2) (Mean rank=2.25), kemudian pada pie dengan formula kontrol (FO) (Mean rank=2.14) dan yang mendapat penilaian kesukaan terendah adalah biskuit MP-ASI Kemenkes RI (Mean rank=1,6). Tidak terdapat beda yang signifikan antara F0 dan F2 ( $p=0.317)$ sedangkan F2 dan biskuit MP-ASI Kemenkes memiliki beda yang signifikan $(p=0.001)$. Pie lebih disukai oleh anak usia 12-24 bulan karena dari aspek warna lebih memiliki variasi warna ungu sehingga lebih menarik, dari aspek aroma memiliki aroma yang netral, tekstur lebih lunak jika dibandingkan dengan tekstur biskuit dan rasa pie manis cenderung disukai daripada bikuit yang memiliki after taste pahit.

Tabel 7. Distribusi Hasil Uji Laboratorium Kandungan Zat Gizi Makro, Hasil Perhitungan DKBM Tiap 100 Gram Pie, Kandungan Zat Gizi Makro Biskuit Mp-ASI Kemenkes RI Tiap 100 Gram, Standar Kudapan Anak Usia 1-3 Tahun Berdasarkan AKG 2013

\begin{tabular}{|c|c|c|c|c|}
\hline Keterangan & Energi (Kkal) & Protein (g) & Lemak (g) & Karbohidrat (g) \\
\hline $\begin{array}{l}\text { Hasil perhitungan } \\
\text { DKBM }\end{array}$ & 415.7 & 9.4 & 16.6 & 54.7 \\
\hline Hasil Uji Laboratorium & 361.7 & 8.8 & 8.7 & 61.8 \\
\hline $\begin{array}{l}\text { Biskuit MP-ASI } \\
\text { Kemenkes }\end{array}$ & 450 & 9 & 14 & 71 \\
\hline $\begin{array}{l}\text { Kandungan tiap sajian } \\
\text { pie }\end{array}$ & 104.9 & 2.5 & 2.5 & 17.9 \\
\hline $\begin{array}{l}\text { Standar Kudapan } \\
\text { (10-15\% AKG) }\end{array}$ & 112,5 & $2.6-3.9$ & 6.6 & 23.25 \\
\hline
\end{tabular}

\section{Kandungan Zat Gizi dan Penentuan Anjuran Porsi} Konsumsi

Uji laboratorium pada formula terbaik (F2) dilakukan untuk mengetahui adanya penyusutan nilai kandungan gizi akibat proses pemasakan. Berdasarkan tabel 7, terdapat perbedaan nilai protein dan lemak pada F2 berdasarkan Hasil uji laboratorium F2 dibandingkan dengan hasil perhitungan DKBM yaitu kandungan zat gizi protein dan lemak lebih rendah. Hasil perhitungan berdasarkan DKBM merupakan perhitungan dari komposisi bahan mentah sedangkan hasil perhitungan uji laboratorium merupakan perhitungan kandungan dari pie yang sudah jadi. Adanya perbedaan nilai protein dan lemak ini menunjukkan adanya penyusutan akibat proses pemasakan. Dengan demikian perhitungan kandungan gizi berdasarkan DKBM hanya digunakan untuk menentukan formula terbaik, Sedangkan untuk menentukan anjuran porsi pie digunakan nilai kandungan gizi pie berdasarkan hasil uji laboratorium.

Jika dibandingkan dengan kandungan gizi F2 dengan biskuit MP-ASI kemenkes RI semua zat gizi makro protein, lemak dan karbohidrat masih lebih rendah. Namun, Jika dibandingkan dengan standar kudapan F2 memiliki kandungan gizi yang lebih tinggi yaitu enegi 3,2 kali lebih tinggi, protein 3,3 kali lebih tinggi, lemak 1,3 kali lebih tinggi dan karbohidrat 2,6 kali lebih tinggi. Dengan demikian pie $\mathrm{F} 2$ ini memiliki kandungan gizi yang lebih padat jika dibandingkan dengan standar kudapan, sehingga jumlah porsi pie yang perlu dikonsumsi lebih sedikit daripada kudapan biasa. Hal ini memungkinkan baduta untuk dapat menghabiskan pie sesuai porsi yang dianjurkan.

Rekomendasi sajian pie per hari jika digunakan untuk menggantikan peran biskuit MP-ASI kemenkes adalah 4 keping pie. Jika dibandingkan dengan anjuran

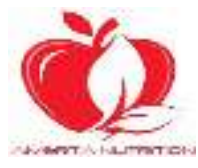

(C)2019. Ahmad dan Rifqi. Open access under CC BY - SA license.

Received: 11-07-2019, Accepted: 19-08-2019, Published online: 27-12-2019.

doi: 10.20473/amnt.v3.i4.2019 284-290, Joinly Published by IAGIKMI \& Universitas Airlangga 
konsumsi biskuit MP-ASI Kemenkes sesuai dengan petunjuk teknis PMT untuk anak usia 12-24 bulan dianjurkan untuk mengkonsumsi biskuit sebanyak 12 keping dalam satu hari ${ }^{3}$. Berdasarkan laporan evaluasi program pemberian makanan tambahan pada Baduta kurang gizi di beberapa kabupaten menunjukkan hasil bahwa Baduta tidak mampu menghabiskan jumlah biskuit sesuai porsi yang diberikan ${ }^{6}$. Baduta yang dapat menghabiskan biskuit yang diterima sebanyak $32 \%$. Rendahnya angka tersebut berkontribusi terhadap compliance baduta terhadap PMT yaitu sebesar $73,2 \%{ }^{12}$. Dengan demikian, harapannya inovasi pie ini dapat menghindarkan baduta dari rasa bosan karena harus menghabiskan kudapan dalam jumlah yang banyak. Pie ini selain dapat difungsikan sebagai PMT pemulihan, juga dapat difungsikan sebagai makanan selingan atau kudapan biasa. Jika dijadikan sebagai kudapan biasa untuk baduta normal cukup 2 keping pie dalam sehari sudah dapat memenuhi $10-15 \%$ kebutuhuan gizi harian berdasarkan AKG $2013^{13}$.

Kelebihan pie yang disubstitusi dengan tepung biskuit MP-ASI Kemenkes RI dan isolat protein kedelai adalah lebih diterima oleh anak usia 12-24 bulan. Pie menjadi variasi bentuk MP-ASI selain biskuit sehingga Baduta tidak merasa bosan. Selain itu, pie ini menjadi MPASI yang lebih padat gizi dibandingkan biskuit MP-ASI Kemenkes sehingga anjuran megkonsumsi pie dalam sehari jumlahnya lebih sedikit daripada anjuran mengkonsumsi biskuit MP-ASI Kemenkes dalam sehari. Adapun kelemahannya adalah kandungan zat gizi makro dalam 100 gram pie masih lebih rendah jika dibandingkan kandungan zat gizi makro biskuit MP-ASI Kemenkes RI.

\section{KESIMPULAN}

Formula Pie modifikasi terbaik adalah formula kedua (F2) yaitu pie dengan substitusi tepung biskuit MPASI $20 \%$ dan isolat protein kedelai $20 \%$. Daya terima F2 lebih tinggi daripada biskuit MP-ASI menurut penilaian panelis ibu dan anak usia 12-24 bulan. Kandungan zat gizi makro pada pie F2 tiap $100 \mathrm{~g}$ masih lebih rendah jika dibandingkan biskuit MP-ASI. Namun demikian, jumlah anjuran konsumsi sajian F2 lebih sedikit dibandingkan biskuit MP-ASI.

\section{ACKNOWLEDGEMENT}

Ucapan terima kasih disampaikan kepada Kemenkes RI yang telah memberikan bantuan dana dalam penelitian ini melalui dana hibah penelitian dengan tema 1000 Hari Pertama Kehidupan (HPK) dari Kementrian Kesehatan Republik Indonesia, Ibu kader posyandu Tenggilis yang turut mendukung terselenggaranya uji kesukaan pada panelis tidak terlatih, Pihak Bakesbangpol dan Dinas Kesehatan Kota Surabaya yang telah mengizinkan terselanggaranya penelitian ini dan kepada bapak dan ibu dosen gizi Universitas Airlangga yang selalu membimbing dalam penelitian ini.

\section{REFERENSI}

1. Masyarakat, D. G., Jenderal, D., Masyarakat, K. \& Kesehatan, K. HASIL PEMANTAUAN STATUS GIZI ( PSG ) TAHUN 2016.

2. Merryana, A. \& Wirjatmadi, B. Pengantar Gizi Masyarakat. (Kencana Prenanda Media Group, 2012).

3. Kementerian Kesehatan RI. Petunjuk Teknis Pemberian Makanan Tambahan (Balita-Ibu HamilAnak Sekolah). (Kementrian Kesehatan RI, 2017).

4. Ditjen Bina Gizi Kesehatan Ibu dan Anak. Panduan Peenyelenggaraan Pemberian Makanan Tambahan Pemulihan Bagi Balita Gizi Kurang (Bantuan Operasional Kesehatan). (Kementerian Kesehatan RI, 2011).

5. Yuandari, M. Gambaran Konseling Gizi Pada Balita Bawah Garis Merah (BGM) Berdasarkan Pedoman Konseling Gizi DEPKES RI Tahun 2008. (Universitas Jember, 2012).

6. Indriati, R., Nugraheni, S. A. \& Kartini, A. Evaluasi Program Pemberian Makanan Tambahan Pemulihan Pada Balita Kurang Gizi Di Kabuaten Wonogiri Ditinjau Dari Aspek Input dan Proses. Manaj. Kesehat. Indones. 3, 18-26 (2015).

7. Nurina, R. Program Pemberian Makanan Tambahan untuk Peningkatan Status Gizi Ibu Hamil Dan Balita Di Kecamatan Cilamaya Kulon Dan Cilamaya Wetan, Karawang. J. Care 1, 44-49 (2016).

8. Adriani, M. \& Wirjatmadi, B. Peranan Gizi dalam Siklus Kehidupan. (Kencana Prenanda Media Group, 2016).

9. Bradbury, J. H. \& Holloway, W. D. Chemistry of Tropical Root Crops : Significance for Nutrition and Agriculture in the Pacific. (Chemistry Department Australian National University, 1988).

10. Saleh, N., Rahayuningsih, S. A. \& Widodo, Y. Profil Dan Peluang Pengembangan Ubi Jalar Untuk Mendukung Ketahanan Pangan Dan Argoindustri. Palawija 15, 21-30 (2008).

11. Persatuan Ahli Gizi Indonesia. Daftar Komposisi Bahan Makanan Indonesia. (2010).

12. Hermina. Evaluasi Pelaksanaan Program Pemberian Makanan Tambahan (PMT) Untuk Balita Kurus Dan Ibu Hamil Kurang Energi Kronis (KEK). (2017).

13. Kementerian Kesehatan RI. Peraturan Mentri Kesehatan (Permenkes) No.75 Tahun 2013 tentang Angka Kecukupan Gizi (AKG). (2013).

14. Pudjiati, S. R. R. \& Masykouri, A. Mengasah Kecerdasan Di Usia 0-2 Tahun. (Kementerian Pendidikan Nasional, 2011).

15. Kementerian Kesehatan RI. Keputusan Menteri Kesehatan Republik Indonesia No 224/Menkes/SK/II/2007 Tentang Spesifikasi Teknis Makanan Pendamping Air Susu Ibu. (2007). 